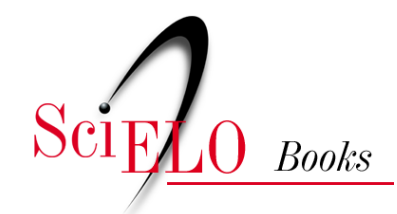

\title{
A espetacularização do lazer em Volta Redonda os investimentos esportivos
}

\author{
Fábio Salgado Araújo
}

\section{SciELO Books / SciELO Livros / SciELO Libros}

ARAÚJO, F.S. A espetacularização do lazer em Volta Redonda: os investimentos esportivos. In: MARAFON, G.J., and RIBEIRO, M.A. orgs. Revisitando o território fluminense, VI [online]. Rio de Janeiro: EDUERJ, 2017, pp. 305-325. ISBN: 978-85-7511-457-5.

https://doi.org/10.7476/9788575114575.0016.

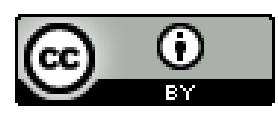

All the contents of this work, except where otherwise noted, is licensed under a Creative Commons Attribution 4.0 International license.

Todo o conteúdo deste trabalho, exceto quando houver ressalva, é publicado sob a licença Creative Commons Atribição $\underline{4.0}$.

Todo el contenido de esta obra, excepto donde se indique lo contrario, está bajo licencia de la licencia $\underline{\text { Creative Commons }}$ Reconocimento 4.0. 


\title{
A espetacularização do lazer em Volta Redonda: os investimentos esportivos ${ }^{1}$
}

\author{
Fábio Salgado Araújo ${ }^{2}$
}

\section{Introdução}

$\mathrm{N}$ as duas últimas décadas, a cidade de Volta Redonda passou por grandes transformações com a privatização da Companhia Siderúrgica Nacional (CSN), ocorrida em 1993. Com isso, houve o afastamento definitivo da CSN do fomento de políticas sociais e dos investimentos em melhorias urbanas, o que levou a prefeitura a assumir maior responsabilidade em relação aos problemas vivenciados pelo município, efetuando intervençōes mais diretas sobre o espaço urbano. Portanto, o poder público municipal estabeleceu um conjunto de políticas e aumentou os investimentos nas áreas de saúde, educação, esporte e lazer.

O objetivo é dinamizar a economia pós-privatização, por meio de investimentos na infraestrutura urbana do município e em políticas sociais. Houve investimentos na construção/recuperação de praças, viadutos, avenidas, monumentos etc., juntamente com os investimentos sociais em saúde, educação, cultura, esporte e lazer; a prefeitura procura descolar a imagem da cidade vinculada à CSN para uma cidade baseada em qualidade de vida, bem-estar e cidadania.

Assim, atualmente o Poder Público municipal procura alterar a imagem da cidade vinculada à empresa (cidade do aço) para a de uma cidade tida como moderna. Busca, assim - através de uma gestão considerada inovadora e do city marketing -, criar uma imagem associada ao bem-estar social e à cidadania, com a realização de investimento em diversas áreas sociais. Entre esses investimentos

${ }^{1}$ Este texto é parte da dissertação intitulada "As transformaçôes do lazer em Volta Redonda-RJ: dos clubes sociorrecreativos vinculados à CSN aos novos investimentos esportivos da Prefeitura”, apresentada ao Programa de Pós-Graduação em Geografia da UERJ, em agosto de 2013, orientada pelo Prof. Dr. Miguel Angelo Campos Ribeiro.

2 Mestre e doutorando em Geografia pelo Programa de Pós-Graduação em Geografia do Instituto de Geografia - Universidade do Estado do Rio de Janeiro (UERJ). 
sociais, destacam-se aqueles associados ao lazer, principalmente os esportivos, com a prefeitura ressaltando seus benefícios para a qualidade de vida da população.

Essa nova orientação da política urbana tem por objetivo promover a cidade e atrair novos investidores, na tentativa de fortalecer a centralidade regional na área de comércio e prestação de serviços. No entanto, os investimentos em lazer, principalmente aqueles ligados aos esportes, apesar dos benefícios que apresentam, precisam ser questionados.

$\mathrm{Na}$ atualidade, o lazer se inscreve no modelo capitalista de produção, sendo utilizado pelo poder público municipal, como já assinalado, para produzir a imagem de uma cidade com boa qualidade de vida. Desse modo, há um lazer espetacularizado, em que a população vive em um simulacro cooptado pelo discurso do poder público municipal.

\section{Volta Redonda: uma cidade em transformação}

O município de Volta Redonda (Figura 1), localizado na região de governo denominada Médio Paraíba, pertence à microrregião do Vale do Paraíba, pertencente à mesorregião Sul Fluminense. Essa região é cortada pelo rio Paraíba do Sul, responsável por seu nome, devido a um acidente geográfico em seu curso.

Figura 1. Mapa com a localização de Volta Redonda (RJ)

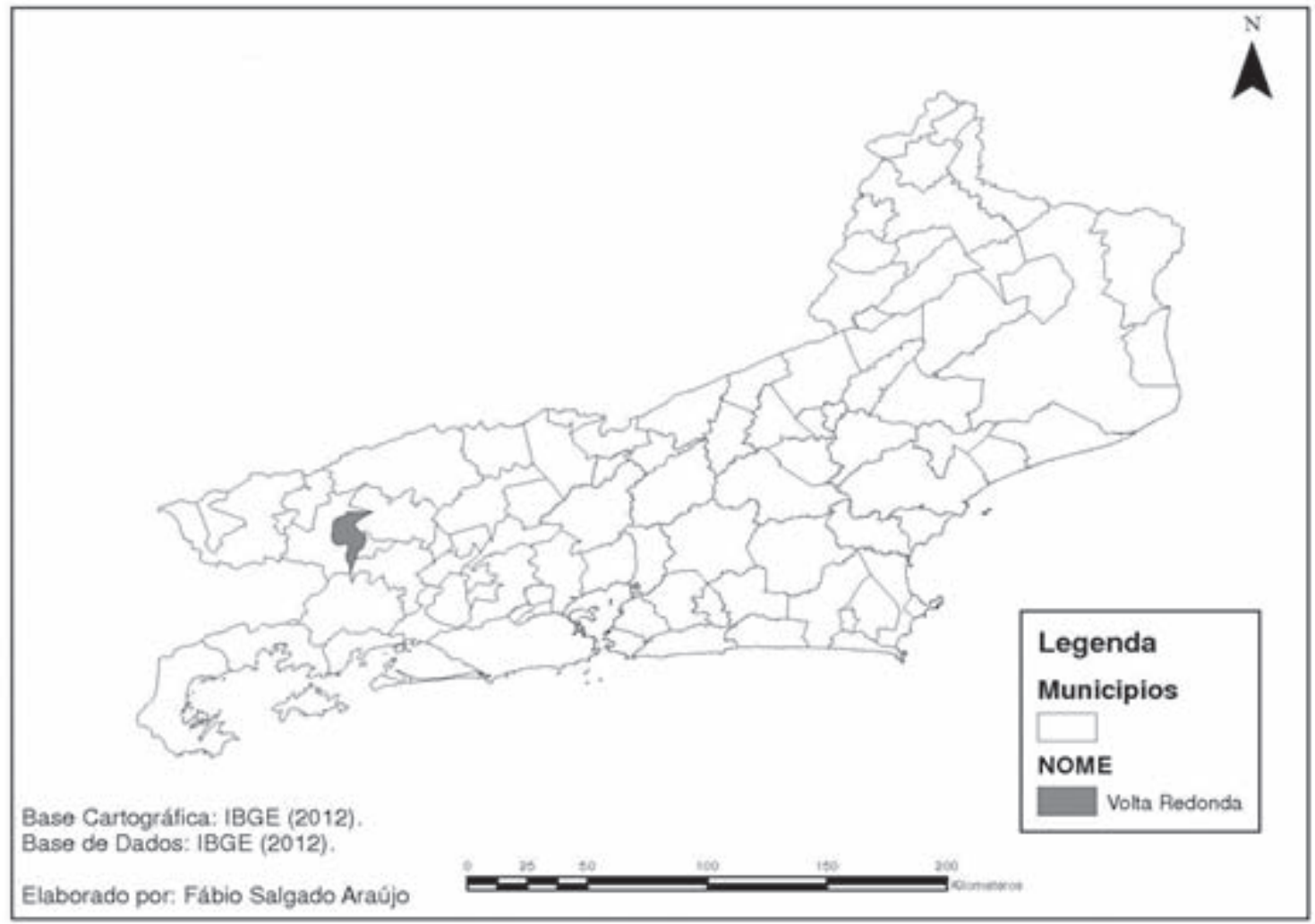

Fonte: Elaborado pelo autor (2012). 
A história do município começou no século XVIII, com a colonização do médio Vale do Paraíba fluminense ligado ao ciclo do café. Entretanto, com a escolha do local para a instalação da Companhia Siderúrgica Nacional (CSN) na década de 1940, grandes mudanças estavam por vir.

A cidade, juntamente com a siderúrgica, foi planejada a partir do modelo de cidade industrial idealizado pelo arquiteto socialista-utópico francês Tony Garnier. Esse modelo foi adaptado pelo também arquiteto Attílio Corrêa Lima, ligado ao autoritarismo populista de Getulio Vargas. O objetivo era transformar Volta Redonda numa cidade-modelo, uma experiência exemplar, com um planejamento residencial que evidenciasse a hegemonia dos mais graduados na empresa.

De acordo com Lopes (1993), o plano de Volta Redonda deveria contribuir para exaltar o industrialismo, sublinhar a política social do governo e espacializar, através do desenho e do equipamento da cidade, o homem novo que estava sendo construído. A elaboração do plano urbanístico da cidade foi influenciada pelo modelo urbanístico norte-americano, com o zoneamento indicando especialização por área e ordenação dos fluxos, inclusive de áreas e equipamentos destinados ao lazer. Previa-se uma cidade linear, com um desenho simples e equilibrado, e suas principais funçôes bem articuladas. A área central seria ocupada pelo centro comercial, desenvolvendo-se paralelamente à usina e concentrando toda a infraestrutura. A CSN seria um modelo autárquico segundo o qual a empresa utilizaria diversas estratégias para educar, vigiar e controlar o trabalhador dentro e fora da fábrica. A estrutura da vila operária, por sua vez, reproduzia a estrutura disciplinar da usina, com um arranjo espacial que representava essa ordem. Havia, dessa forma, um duplo controle dos trabalhadores, configurando uma verdadeira company-town (Calife, 2000; Moreira, 2000; Fontes e Lamarão, 2006; Piquet, 1998).

O não aproveitamento de todos os trabalhadores que construíram a usina gerou uma desmobilização da mão de obra empregada na construção e, por conseguinte, um crescimento desordenado e desvinculado dos interesses imediatos da empresa. Com isso, na margem esquerda do Rio Paraíba, surgia outra Volta Redonda, ocupada de forma não planejada por pequenos comerciantes e por aquela massa de trabalhadores dispensados da CSN. Os dois núcleos originais de Santo Antônio de Volta Redonda tornaram-se o eixo de ligação entre os bairros planejados e os novos bairros que surgiram nesse processo de crescimento.

Assim, Volta Redonda ficaria dividida em duas: à margem direita do rio, desenvolvia-se o núcleo urbano, a partir do projeto dos bairros operários - a chamada "Cidade Nova" -, e, à margem esquerda, a chamada "Cidade Velha", separada da CSN e sem dispor dos serviços da parte planejada. Assim, os trabalhadores não aproveitados pela CSN foram deslocados para a parte "velha" ou para a periferia da cidade, e os proprietários de algumas fazendas da região se converteram em loteadores e especuladores. Com isso, a cidade conheceu uma considerável expansão da malha urbana (principalmente nas décadas de 1950 e 1960), com a implantação de numerosos loteamentos que deram origem a novos bairros, principalmente na margem esquerda do rio Paraíba do Sul.

Nesse contexto, o processo de ocupação de Volta Redonda gerou uma malha urbana descontínua e rarefeita, com grandes vazios e áreas urbanas enquistadas, subindo os morros e instalando-se em pequenas áreas de baixada. Não apenas as características físicas definiram essa ocupação, como também o fato de as melhores terras estarem nas mãos da CSN e de alguns fazendeiros (Calife,; Moreira, 2000; Fontes e Lamarão, 2006). 
Nas décadas de 1960 e 1970, a CSN começou a reduzir seus encargos com moradias para funcionários, vendendo as casas por meio da criação de uma imobiliária. Também se desfez de seu patrimônio público - ruas, praças, serviços urbanos etc. - e dos encargos decorrentes de sua manutenção, passando-os para a Prefeitura Municipal. Assim, no dia $1^{\circ}$ de janeiro de 1968, a prefeitura municipal e a CSN assinaram um termo de entrega e recebimento dos serviços urbanos, dando início ao processo de unificação do espaço urbano, ao reunir, sob a mesma administração, a cidade operária e a cidade velha. Essa medida, contudo, multiplicou os encargos da administração municipal, que não se encontrava preparada para tanto, passando para a responsabilidade da prefeitura o fornecimento desses serviços. O impacto dessa transferência foi significativo, pois até mesmo a água que abastecia os bairros da cidade planejada era fornecida pela CSN (Costa, 2004).

A crise na década de 1980 e o acúmulo de dívidas da CSN foram fatores que contribuíram para a estagnação econômica do município. As políticas governamentais em nível nacional empreendidas desde o fim da década de 1980 levaram ao processo de privatização da usina em 1993, dando origem à maior crise vivida pelo município em sua história. Com essa privatização, diminuiu a intervenção da siderúrgica diretamente sobre a cidade, com sua retirada da dotação de infraestrutura urbana e o encerramento das políticas sociais empreendidas pela empresa.

A CSN continua a ser importante para o município. No entanto, para enfrentar os graves problemas sociais, ambientais e econômicos que culminaram com a privatização, houve um processo de reestruturação de Volta Redonda. Assim, o poder público municipal tem aumentado a presença e o poder no fomento de políticas públicas e sociais.

O poder público municipal, principalmente a partir de 1997, promoveu alterações na estrutura administrativa da cidade, com novos investimentos procurando desenvolver o setor de comércio e serviços. Houve a construção/reforma de equipamentos e mobiliário urbano, principalmente aqueles ligados a saúde, educação, lazer e esporte. Esses novos investimentos em infraestrutura, equipamentos e mobiliário foram mais concentrados nos bairros centrais, que são áreas contíguas à CSN. Assim, reforçou-se a centralidade de determinados bairros, induzindo o setor privado a fazer investimentos em determinadas áreas, enquanto deixava outras desassistidas.

Nesse contexto, no início deste século, Volta Redonda vive um período de grande transformação, em que o poder público municipal procura substituir a imagem vinculada à empresa (cidade do aço) pela imagem de uma cidade moderna, baseada em outros parâmetros, como, por exemplo, cidadania. Para isso, vem investindo na construção e reforma de equipamentos urbanos para criar uma imagem de progresso e construir um consenso junto à população em torno das intervenções urbanas aplicadas. Procura-se, assim, sugerir à população uma recuperação econômica após a crise vivida pelo município depois da privatização. Esse discurso político tem alto poder de legitimação junto às classes trabalhadoras órfãs do paternalismo da CSN, outrora presente. Por essa razão, testemunham-se investimentos em diversas áreas sociais, com destaque para o lazer, principalmente na área esportiva (Oliveira e Mascarenhas, 2007; Souto, 2007; Palmeira, 2012). 


\title{
3. Os novos investimentos em lazer: a espetacularização dos eventos esportivos
}

As mudanças empreendidas pela CSN na década de 1960 também conduziram a uma diminuição de investimentos por parte da empresa em infraestrutura e investimentos em lazer. Desde o final da década de 1960 e o início da década de 1970, não foram mais criados equipamentos de lazer pela empresa. Com o forte crescimento urbano a partir de 1970, teve início um aumento dos investimentos da prefeitura em equipamentos e atividades de lazer para a população da cidade, principalmente para os moradores não vinculados à siderúrgica.

Entretanto, em Volta Redonda os investimentos em lazer ficaram estagnados durante toda a década de 1980 e parte dos anos 1990, sendo retomados apenas no final da última década do século XX. Nesse momento, então, o lazer aparece, em consonância com a Constituição Federal de 1988, como uma preocupação do Poder Público municipal, integrando a Lei Orgânica Municipal (1990), e posteriormente reafirmado no Plano Diretor (2008). Na Lei Orgânica (1990), o compromisso do poder municipal é expresso da seguinte forma:

\begin{abstract}
O município assegurará o exercício ao direito ao lazer, mediante a oferta de equipamento e de área pública de lazer para fins de recreação, esportes e execução de programas culturais e turísticos. O município proporcionará meios de recreação à comunidade mediante reserva de espaços livres e verdes em forma de parques, bosques e jardins. Os serviços municipais de esportes e recreação articular-se-ão com atividades culturais do município (Lei Orgânica Municipal, 1990, p. 76).
\end{abstract}

Assim, não houve apenas o aumento dos investimentos em infraestrutura e equipamentos de lazer por parte do município; o Poder Público municipal também passou a incentivar e fomentar o lazer de caráter privado, atraindo investimentos como lojas de departamentos, shopping centers, restaurantes, hotéis e bares, aliados a eventos e espetáculos, como shows, concertos, exposições, eventos esportivos, entre outros, direcionando o lazer para o consumo e o espetáculo.

Para Debord (1997), o espetáculo é uma forma de expressão da sociedade, em que a vida real é pobre e fragmentada, e os indivíduos são obrigados a contemplar e a consumir passivamente as imagens de tudo o que lhes falta na existência real. Nesse sentido, o autor aponta que a sociedade se resume a um acúmulo de espetáculos em que as situações e as relações sociais formam uma realidade paralela que serve de objeto de contemplação e ilusão para as pessoas. Foi nesse contexto que se seguiram os investimentos em lazer na pós-privatização. Houve um acúmulo de eventos relacionados ao lazer no município, formando uma realidade paralela de boa qualidade de vida com cidadania que não condiz com a realidade socioespacial urbana.

A sociabilidade no espaço urbano do município se caracteriza por esses eventos, que ocorrem de maneira pontual no tecido urbano e de forma presenteísta. Portanto, o tempo do não trabalho na cidade é marcado por eventos em que os moradores da cidade se identificam cada vez mais com o discurso elaborado pela prefeitura. Assim, para se compreender o lazer na cidade, é necessário também compreender o discurso da prefeitura, alardeado, de forma ostensiva, 
nos outdoors espalhados pela cidade e veiculado nos principais meios de comunicação. Os espetáculos apresentam-se como a própria sociedade. Trata-se de uma relação social, resultado do mundo da produção em que a informação voltada ao entretenimento constitui o modelo de vida socialmente dominante. A prática do lazer, seja no espaço público, seja no privado, ganha uma dimensão cada vez maior na sociedade atual - e isso é o que também ocorre no município de Volta Redonda (Debord, 1997).

É por meio de projetos/programas e eventos que a prefeitura apresenta Volta Redonda como um município com qualidade de vida e cidadania, em que os moradores têm acesso a saúde, educação, habitação e lazer - uma tentativa de recuperar a autoestima da população, afetada pela crise gerada com a privatização. Nesse sentido, há uma espetacularização das atividades de lazer na cidade, com ativa participação da população. Assim, cria-se a imagem de uma cidade com boa qualidade de vida e cidadania, um espaço em que todos têm acesso a lazer de qualidade. Essa imagem é uma abstração do real generalizado, consequência de uma sociedade capitalista em que o espetáculo é a forma mais desenvolvida.

Assim, essa cidade imaginada e presente apenas no discurso do poder público municipal não existe de fato; trata-se de um simulacro (Figura 2), que busca minimizar os problemas sociais e ambientais que a cidade enfrenta, como, por exemplo, destinação final do lixo, tratamento de esgoto, ilhas de calor, falta de áreas verdes na cidade, além de questóes relacionadas a trânsito e especulação imobiliária que geram uma sobrecarga na infraestrutura do município. Entretanto, esse simulacro é mais atraente para o cidadão, agora espectador, do que a realidade urbana em si. Os simulacros representam e ressignificam a simulação, a aparência externa, copiando e imitando a realidade. Por outro lado, esses simulacros dão visibilidade às cenas, excluindo a dimensão da subjetividade e tornando tudo visível e público. Desse modo, a realidade deixou de existir e passa-se a viver a representação da realidade fortemente difundida pela prefeitura (Baudrillard, 1981).

Os investimentos em inúmeros projetos/programas destinados ao lazer (que, além de variados, atendem de crianças a pessoas na terceira idade), passando por centenas de eventos anuais nas áreas cultural e esportiva, o tempo vivido e sua linearidade, tudo isso perde sentido no espaço urbano do município. Um bom exemplo é a quantidade de eventos culturais realizados anualmente na cidade. A Tabela 1 mostra a quantidade, os locais e a descrição dos eventos realizados em 2013. 


\section{A espetacularização do lazer em Volta Redonda: os investimentos esportivos}

Figura 2. Outdoor da propaganda institucional da prefeitura

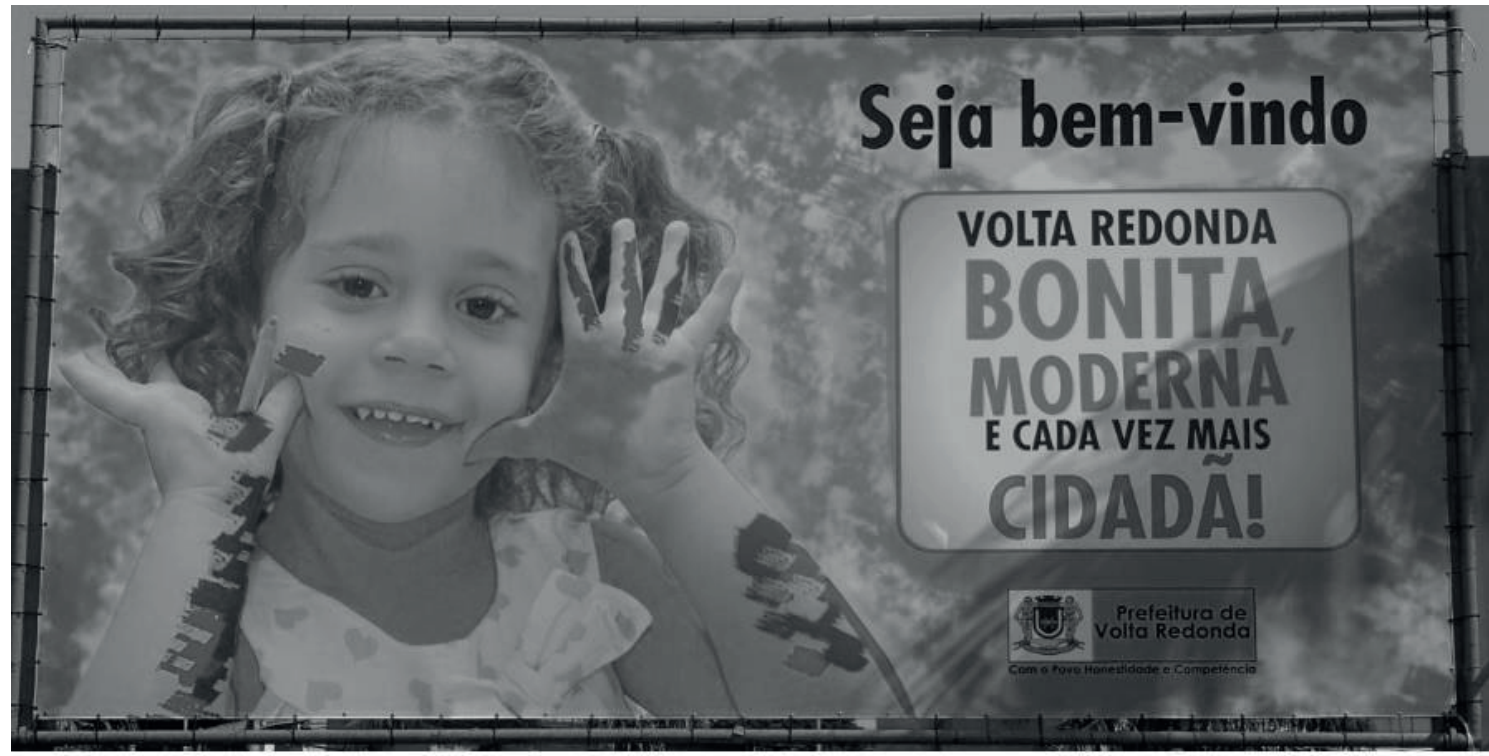

Fonte: Arquivo pessoal, 2015.

Tabela 1. Quantidade, localização e descrição dos eventos realizados pela Secretaria Municipal de Cultura para o ano 2013

\begin{tabular}{|c|c|c|}
\hline $\begin{array}{l}\text { Quantidade } \\
\text { de eventos }\end{array}$ & Localização & Descrição dos eventos \\
\hline 30 & Memorial Zumbi & $\begin{array}{l}\text { Realização de shows musicais, teatro e exposiçôes. Exemplos: "Freakshow", } \\
\text { "Roda de Samba", "Dia da Consciência Negra". }\end{array}$ \\
\hline 200 & Eventos nos bairros & $\begin{array}{l}\text { Duas apresentaçôes semanais de espetáculos nos bairros da cidade. Exemplos: } \\
\text { "Arena de Viola", "Cinema nos Bairros", "Baile Popular", "Seresta no Bairro", } \\
\text { "Roda Musical" e "Palco Sobre Rodas". }\end{array}$ \\
\hline 20 & Espaço Zélia Arbex & $\begin{array}{l}\text { Exposiçôes artísticas relacionadas a fotografia e artes plásticas, entre outras. } \\
\text { Exemplos: "Saláo do Humor", "Olhar } 180^{\circ} \text { ". } \\
\end{array}$ \\
\hline 50 & Ilha São João & $\begin{array}{l}\text { Local para realização de grandes eventos e exposiçōes. Exemplos: "Volta Redon- } \\
\text { da do Rock", "Feira da Primavera", "Folia de Reis", "Feira Regional do Livro", } \\
\text { "Encontro de Carros Antigos". }\end{array}$ \\
\hline 90 & Zoológico Municipal & Apresentações de teatro infantil nos fins de semana. \\
\hline 45 & "Cultura para Todos" & Apresentação gratuita de shows musicais com artistas regionais e nacionais \\
\hline 90 & $\begin{array}{l}\text { Memorial } \\
\text { Getulio Vargas }\end{array}$ & $\begin{array}{l}\text { Realização de eventos diversos. Exemplos: "Feira de Artesanato", "Vila Cultural", } \\
\text { "Grito do Rock", "Banda Municipal". }\end{array}$ \\
\hline
\end{tabular}

Fonte: Secretaria Municipal de Cultura, 2013. 
Em 2013, esses eventos reuniram cerca de duzentas mil pessoas. Planeja-se aumentar em 15\% o número de eventos até 2017 (passando dos atuais 525 eventos anuais para 605), com uma previsão de gasto de cerca de R $\$ 8$ milhões. Os eventos esportivos também aumentaram nos últimos anos, devido à ação da Prefeitura, que tem procurado atrair e incentivar sua promoção. ${ }^{3}$ São promovidos no município torneios esportivos de futebol, basquete e vôlei, competiçôes de natação, atletismo e ginástica artística e torneios esportivos estudantis; para a terceira idade, além de competiçôes para portadores de necessidades especiais, realizam-se eventos esportivos estaduais e nacionais. ${ }^{4}$ Os gastos com esses eventos em 2013 foram de R \$ 3,7 milhões; e a previsão é de que aumente o número de eventos esportivos e o montante de investimentos, que deverá ser superior a $\mathrm{R} \$ 7$ milhões em 2017.5

Esse aumento dos investimentos na área esportiva refere-se tanto aos equipamentos como aos programas e projetos. Tais investimentos estão voltados ao esporte de desempenho, ao esporte-educação e ao esporte-lazer. ${ }^{6}$ A maior parte dos programas/projetos e da construção/reforma de equipamentos esportivos é desenvolvida pela Secretaria Municipal de Esporte e Lazer, com recursos da prefeitura e oriundos de convênios com o governo estadual e o Ministério dos Esportes.

Nos últimos dez anos, Volta Redonda recebeu do Ministério do Esporte cerca de R\$ 30 milhôes para a realização de atividades ligadas ao esporte, sendo R \$ 12 milhões apenas nos últimos quatro anos. Foi o segundo maior número de convênios da prefeitura com a União, perdendo apenas para o Ministério da Saúde, e o segundo maior volume, atrás somente do Ministério das Cidades. Na Tabela 2, verificamos a quantidade de verba recebida pela prefeitura e sua destinação, além da contrapartida realizada pelo poder público municipal.

Tabela 2. Repasses do Ministério dos Esportes para a prefeitura (1997-2013)

\begin{tabular}{|l|l|l|l|}
\hline $\begin{array}{l}\text { No de } \\
\text { registros }\end{array}$ & Projetos Conveniados & Valor do Convênio & $\begin{array}{l}\text { Valor da } \\
\text { Contrapartida }\end{array}$ \\
\hline 38 & Construção e reforma de infraestrutura esportiva & $\mathrm{R} \$ 8.518 .308,42$ & $\mathrm{R} \$ 6.851 .607,64$ \\
\hline 18 & Núcleos de esporte e lazer & $\mathrm{R} \$ 6.234 .985,50$ & $\mathrm{R} \$ 2.834 .759,86$ \\
\hline 10 & Programa "Esporte Solidário" & $\mathrm{R} \$ 1.469 .321,57$ & $\mathrm{R} \$ 1.264 .269 .54$ \\
\hline 15 & Esporte paralímpico & $\mathrm{R} \$ 2.061 .805,05$ & $\mathrm{R} \$ 1.045 .328,68$ \\
\hline
\end{tabular}

3 A Secretaria Municipal de Esporte e Lazer não informou a quantidade de eventos esportivos realizados em 2013.

${ }^{4}$ Mais informações podem ser obtidas no site: www.portalvr.com/smel/secretaria.php

5 Os valores programados foram redimensionados devido à crise econômica por que passa o estado do Rio de Janeiro, porém não foram informados pela secretaria.

${ }^{6}$ Esporte de desempenho: é disputado obedecendo-se rigorosamente às regras e aos códigos existentes específicos de cada modalidade esportiva. É o esporte institucionalizado, do qual fazem parte federações internacionais e nacionais que organizam competiçōes em todo o mundo. Esporte-educação: é a manifestação esportiva como mais um processo educativo na formação dos jovens; uma preparação para o exercício da cidadania. Esporte-lazer: apoia-se no princípio do prazer lúdico e na utilização construtiva do tempo livre e da liberdade, promovendo o bem-estar de seus participantes (Tubino, 2007). 


\begin{tabular}{|l|l|l|l|}
\hline $\begin{array}{l}\text { No de } \\
\text { registros }\end{array}$ & Projetos Conveniados & Valor do Convênio & $\begin{array}{l}\text { Valor da } \\
\text { Contrapartida }\end{array}$ \\
\hline 7 & Aquisição e confecção de material esportivo & $\mathbf{R} \mathbf{6 . 3 3 9 . 6 4 8 , 2 4}$ & $\mathbf{R} \mathbf{8 2 8 . 4 8 8 , 5 5}$ \\
\hline 4 & Programa "Segundo Tempo" & $\mathbf{R} \mathbf{1 . 5 3 0 . 6 8 5 , 0 0}$ & $\mathbf{R} \mathbf{1 . 0 8 1 . 0 9 5 , 0 0}$ \\
\hline 3 & Projetos esportivos para a terceira idade & $\mathrm{R} \$ 243.903,03$ & $\mathrm{R} \$ 67.900,00$ \\
\hline 3 & Núcleos esportivos intermunicipais & $\mathbf{R} \mathbf{3 . 9 5 4 . 6 4 2 , 0 0}$ & $\mathbf{R} \mathbf{7 4 9 . 8 7 8 , 0 0}$ \\
\hline
\end{tabular}

Fonte: Sistema Integrado de Administração Financeira do Governo Federal (Siafi). Disponível em: http://www.portaltransparencia.gov.br/convenios. ${ }^{7}$

A maior parte dos investimentos foi direcionada a construção/reforma e aquisição de equipamentos esportivos, soma que ultrapassa R \$ 22 milhões. Em seguida, está o direcionamento dos investimentos para programas e projetos esportivos voltados a crianças e adolescentes em vulnerabilidade social e para a terceira idade, totalizando mais de $\mathrm{R}$ \$ 11 milhôes. Em contrapartida aos repasses recebidos do Ministério do Esporte, a prefeitura gastou cerca de R \$ 15 milhões. Com recursos próprios de seu orçamento, o município tem aumentado seus investimentos em esportes e lazer. Na Tabela 3, observa-se a evolução das receitas orçamentárias da prefeitura e os gastos com esporte e lazer entre os anos de 2007 a 2011.

Tabela 3. Evolução das despesas totais e de esporte e lazer da prefeitura (2007-2011)

\begin{tabular}{|l|l|l|}
\hline Ano & Despesas totais por função & Despesas de esporte e lazer \\
\hline 2007 & $\mathrm{R} \$ 426.016 .500,00$ & $\mathrm{R} \$ 7.495 .200,00$ \\
\hline 2008 & $\mathrm{R} \$ 500.646 .900,00$ & $\mathrm{R} \$ 13.795 .900,00$ \\
\hline 2009 & $\mathrm{R} \$ 582.812 .800,00$ & $\mathrm{R} \$ 18.915 .100,00$ \\
\hline 2010 & $\mathrm{R} \$ 656.962 .400,00$ & $\mathrm{R} \$ 17.336 .200,00$ \\
\hline 2011 & $\mathrm{R} \$ 776.757 .000,00$ & $\mathrm{R} \$ 25.814 .000,00$ \\
\hline
\end{tabular}

Fonte: Dados Contábeis dos Municípios Brasileiros. Finanças do Brasil (Finbra). Disponível em: http://www3.tesouro.fazenda.gov.br/estados_municipios/index.asp.

Entre os anos de 2007 e 2011, as despesas totais por função no município aumentaram cerca de $80 \%$, enquanto as despesas em esporte e lazer aumentaram em $370 \%$. De acordo com os dados da Prefeitura, para 2012 foram gastos R \$ 23 milhões e a previsão para 2013 é de cerca de R \$ 25 milhões anuais em esporte e lazer. A previsão para 2017 é que os gastos atinjam R \$ 53,5 milhões, ou seja, mais

\footnotetext{
7 De acordo com a Procuradoria-Geral da União, convênio é o instrumento que disciplina os compromissos que devem reger as relaçôes de dois ou mais participantes (como, por exemplo, governo federal e prefeitura) que tenham interesse em atingir um objetivo comum, mediante a formação de uma parceria. Os dados dos convênios estão disponíveis em: http://www.portaltransparencia.gov.br/convenios. Para mais informações, acessar: http://www.tesouro.fazenda.gov.br/siafi.
} 
que o dobro de 2013. No município, os gastos com esporte e lazer ocupam a oitava posição, atrás de gastos com administração direta, assistência social, previdência social, saúde, educação, saneamento básico, energia e transporte, e ficando à frente dos gastos com segurança pública, infraestrutura urbana, comunicações, habitação, cultura, trabalho e patrimônio, entre outros.

Esses investimentos esportivos propiciaram um aumento nos programas e projetos, bem como no número de equipamentos esportivos no município, com o intuito de atender não somente o esporte de desempenho, mas principalmente o esporte-educação e o esporte-lazer. Atualmente, Volta Redonda conta com diversos projetos/programas para o atendimento da população. Há programas como escolinhas de futebol, vôlei, badminton, remo, kart, hipismo e ginástica artística e de trampo$\mathrm{lim}$, com a participação dos alunos em competições nacionais e internacionais. Todos esses projetos são desenvolvidos com equipamentos esportivos da Prefeitura.

Os equipamentos são: 14 ginásios poliesportivos, 254 quadras em diferentes bairros (sendo cinquenta cobertas), cinquenta campos de futebol e futebol society. Existem ainda o parque aquático com piscina semiolímpica, o ginásio municipal de skate, o kartódromo, a arena de hipismo, a sede náutica de remo e o estádio Raulino de Oliveira, com capacidade para 25 mil pessoas. Na Tabela 4, podem-se observar o uso e o local dos principais equipamentos esportivos de propriedade da prefeitura, enquanto a Figura 3 mostra a quantidade de equipamentos nos bairros da cidade. Podemos perceber uma concentração desses espaços junto à curva do rio, perto de áreas urbanas não consolidadas - importante notar que a prefeitura não instalou equipamentos esportivos nos bairros construídos pela CSN.

Assim, com o aumento dos investimentos em esportes nos últimos anos, o município de Volta Redonda foi classificado em primeiro lugar no Índice de Desenvolvimento Esportivo (IDE) criado pela Secretaria de Esporte e Lazer do estado do Rio de Janeiro (SEEL), como se observa na Tabela 5. Essa pesquisa foi realizada pela Superintendência de Desportos do estado (Suderj), que traçou um diagnóstico dos 92 municípios fluminense a fim de conhecer o nível de desenvolvimento esportivo. O índice é composto por oito dimensôes: recursos humanos no esporte; articulação institucional; legislação municipal; recursos públicos; convênios e parcerias; ações, programas e projetos esportivos; eventos esportivos; instalações e equipamentos. Com 91 projetos esportivos, Volta Redonda ficou em primeiro lugar, com 3,58 pontos.

Tabela 4. Localização dos equipamentos esportivos e sua finalidade

\begin{tabular}{|l|l|l|}
\hline Equipamento esportivo & Localização & Utilização \\
\hline $\begin{array}{l}\text { Ginásio Poliesportivo } \\
\text { Darcise José de Carvalho }\end{array}$ & $\begin{array}{l}\text { Rua Jaime Martins, } \\
n^{\circ} 850, \text { Santo Agostinho }\end{array}$ & $\begin{array}{l}\text { Atividades esportivas para crianças e adolescentes e para a } \\
\text { comunidade em geral. Atividades específicas para a terceira } \\
\text { idade. }\end{array}$ \\
\hline $\begin{array}{l}\text { Ginásio Poliesportivo Va- } \\
\text { necina Freitas Henrique } \\
\text { Vicente }\end{array}$ & $\begin{array}{l}\text { Av. Presidente Kennedy, } \\
n^{\circ} \text { 6.090, Siderlândia }\end{array}$ & $\begin{array}{l}\text { Atividades esportivas para crianças e adolescentes e para a co- } \\
\text { munidade em geral. Atividades específicas para a terceira idade. }\end{array}$ \\
\hline $\begin{array}{l}\text { Ginásio Poliesportivo } \\
\text { Francisco Gomes do } \\
\text { Nascimento }\end{array}$ & $\begin{array}{l}\text { Rua Cap. BL. Bragança, } \\
n^{\circ} 888, \text { São Geraldo }\end{array}$ & $\begin{array}{l}\text { Atividades esportivas para crianças e adolescentes e para a co- } \\
\text { munidade em geral. Atividades específicas para a terceira idade. }\end{array}$ \\
\hline $\begin{array}{l}\text { Ginásio Poliesportivo } \\
\text { José Alves “Zinho” }\end{array}$ & $\begin{array}{l}\text { Av. dos Ex-combatentes, } \\
\text { s/no, Santa Cruz }\end{array}$ & $\begin{array}{l}\text { Atividades esportivas para crianças e adolescentes e para a co- } \\
\text { munidade em geral. Atividades específicas para a terceira idade. }\end{array}$ \\
\hline
\end{tabular}




\begin{tabular}{|c|c|c|}
\hline Equipamento esportivo & Localizaçãoo & Utilização \\
\hline $\begin{array}{l}\text { Ginásio Poliesportivo } \\
\text { Carlos Augusto Haasis } \\
\text { Filho }\end{array}$ & $\begin{array}{l}\text { Rua } 43 \mathrm{c} / \text { rua } 35 \text {, Vila } \\
\text { Rica (Jd. Tiradentes) }\end{array}$ & $\begin{array}{l}\text { Atividades esportivas para crianças e adolescentes e para a co- } \\
\text { munidade em geral. Atividades específicas para a terceira idade. }\end{array}$ \\
\hline $\begin{array}{l}\text { Ginásio Poliesportivo } \\
\text { Abraham Medina }\end{array}$ & $\begin{array}{l}\text { Rua Triestes, } \mathrm{s} / \mathrm{n}^{\circ} \text {, Ponte } \\
\text { Alta }\end{array}$ & $\begin{array}{l}\text { Atividades esportivas para crianças e adolescentes e para a } \\
\text { comunidade em geral. Atividades específicas para a terceira } \\
\text { idade. }\end{array}$ \\
\hline $\begin{array}{l}\text { Ginásio Poliesportivo } \\
\text { Heth Lustoza Bastos }\end{array}$ & $\begin{array}{l}\text { Rua Érika Berbet, nº 3, } \\
\text { Vila Rica (Três Poços) }\end{array}$ & $\begin{array}{l}\text { Atividades esportivas para crianças e adolescentes e para a } \\
\text { comunidade em geral. Atividades específicas para a terceira } \\
\text { idade. }\end{array}$ \\
\hline $\begin{array}{l}\text { Ginásio Poliesportivo } \\
\text { Amaro Inácio }\end{array}$ & $\begin{array}{l}\text { Av. Antônio de Almeida } \\
\text { Gama, Retiro }\end{array}$ & $\begin{array}{l}\text { Atividades esportivas para crianças e adolescentes e para a } \\
\text { comunidade em geral. Atividades específicas para a terceira } \\
\text { idade. }\end{array}$ \\
\hline $\begin{array}{l}\text { Ginásio Poliesportivo } \\
\text { Nery Miglioly }\end{array}$ & $\begin{array}{l}\text { Rua Vereador Acácio da } \\
\text { Rocha, nº 82, Açude I }\end{array}$ & $\begin{array}{l}\text { Atividades esportivas para crianças e adolescentes e para a } \\
\text { comunidade em geral. Atividades específicas para a terceira } \\
\text { idade. }\end{array}$ \\
\hline $\begin{array}{l}\text { Ginásio Poliesportivo } \\
\text { Gal. Euclydes Figueiredo }\end{array}$ & $\begin{array}{l}\text { Rua Alexandre Polastri } \\
\text { Filho, n } 761 \text {, Ilha São } \\
\text { João }\end{array}$ & $\begin{array}{l}\text { Treinamento profissional e das categorias de base do vôlei } \\
\text { masculino. Realização de torneios e jogos oficiais. }\end{array}$ \\
\hline $\begin{array}{l}\text { Ginásio Municipal de } \\
\text { Skate } \\
\text { Fernando Schimdt }\end{array}$ & $\begin{array}{l}\text { Rua } 848, \mathrm{~s} / \mathrm{n}^{\circ} \text {, Jardim } \\
\text { Tiradentes }\end{array}$ & $\begin{array}{l}\text { Atividades de treinamento. Atividades esportivas para crian- } \\
\text { ças e adolescentes. Realização de torneios amadores. }\end{array}$ \\
\hline $\begin{array}{l}\text { Estádio Municipal Rau- } \\
\text { lino de Oliveira }\end{array}$ & $\begin{array}{l}\text { Rua } 539, \mathrm{~s} / \mathrm{n}^{\circ}, \text { Jardim } \\
\text { Paraíba }\end{array}$ & $\begin{array}{l}\text { Atividades de treinamento profissional de futebol masculino } \\
\text { e feminino. }\end{array}$ \\
\hline $\begin{array}{l}\text { Parque Aquático } \\
\text { Municipal }\end{array}$ & $\begin{array}{l}\text { Rua Alexandre Polastri } \\
\text { Filho, no 791, Ilha São } \\
\text { João }\end{array}$ & $\begin{array}{l}\text { Atividades esportivas para crianças e adolescentes. Atividades } \\
\text { recreativas para a comunidade em geral. Torneiros amadores } \\
\text { de natação. }\end{array}$ \\
\hline $\begin{array}{l}\text { Kartódromo Municipal } \\
\text { de Volta Redonda }\end{array}$ & $\begin{array}{l}\text { Av. Ministro Salgado } \\
\text { Filho, s/no, Aeroclube }\end{array}$ & $\begin{array}{l}\text { Atividades esportivas para criança e adolescentes. Treinamento } \\
\text { e aperfeiçoamento profissional de pilotos. Realização de campe- } \\
\text { onatos amadores e profissionais. }\end{array}$ \\
\hline $\begin{array}{l}\text { Complexo Esportivo Jor- } \\
\text { nalista Oscar Cardoso }\end{array}$ & $\begin{array}{l}\text { Av. Ministro Salgado } \\
\text { Filho, s/no, Aeroclube }\end{array}$ & $\begin{array}{l}\text { Treinamento para as categorias de base de futebol feminino e } \\
\text { masculino. Treinamento profissional. }\end{array}$ \\
\hline $\begin{array}{l}\text { Centro de Artes Marciais } \\
\text { Mestre Boa Viagem }\end{array}$ & $\begin{array}{l}\text { Rua } 539, \text { s/no }, \text { Estádio } \\
\text { Municipal Raulino de } \\
\text { Oliveira, Jardim Paraíba }\end{array}$ & $\begin{array}{l}\text { Atividades esportivas para crianças e adolescentes. Treinamento } \\
\text { semiprofissional. Realização de torneios amadores e } \\
\text { profissionais. }\end{array}$ \\
\hline $\begin{array}{l}\text { Centro Municipal de } \\
\text { Ginástica Artística }\end{array}$ & $\begin{array}{l}\text { Rua } 539, \text { s/no, Estádio } \\
\text { Municipal Raulino de } \\
\text { Oliveira, Jardim Paraíba }\end{array}$ & $\begin{array}{l}\text { Atividades esportivas para crianças e adolescentes. Realização de } \\
\text { torneios amadores. }\end{array}$ \\
\hline $\begin{array}{l}\text { Miniestádio Edgar de } \\
\text { Carvalho }\end{array}$ & $\begin{array}{l}\text { Rua Alexandre Polastri } \\
\text { Filho, no } 791 \text {, Ilha São } \\
\text { João }\end{array}$ & $\begin{array}{l}\text { Atividades esportivas para crianças e adolescentes. Treinamento } \\
\text { profissional. Realização de jogos e torneios profissionais. }\end{array}$ \\
\hline $\begin{array}{l}\text { Arena Esportiva Professor } \\
\text { Paulo Camargo de Melo }\end{array}$ & $\begin{array}{l}\text { Praça Independência e } \\
\text { Luz II, Aterrado }\end{array}$ & $\begin{array}{l}\text { Atividades esportivas para crianças e adolescentes e para a } \\
\text { comunidade em geral. }\end{array}$ \\
\hline
\end{tabular}

Fonte: Secretaria de Esporte e Lazer (SMEL) da Prefeitura Municipal de Volta Redonda. Disponível em: http://www.portalvr.com/smel/centrosesportivos.php. ${ }^{8}$

8 Dados fornecidos pela Secretaria Municipal de Esporte e Lazer para o ano de 2013. Há outros equipamentos esportivos no município, como, por exemplo, aqueles que pertencem aos clubes sociorrecreativos de caráter privado. O levantamento levou em conta apenas os públicos municipais. 
Figura 3. Mapa com a distribuição dos equipamentos esportivos da Prefeitura Municipal de Volta Redonda-RJ

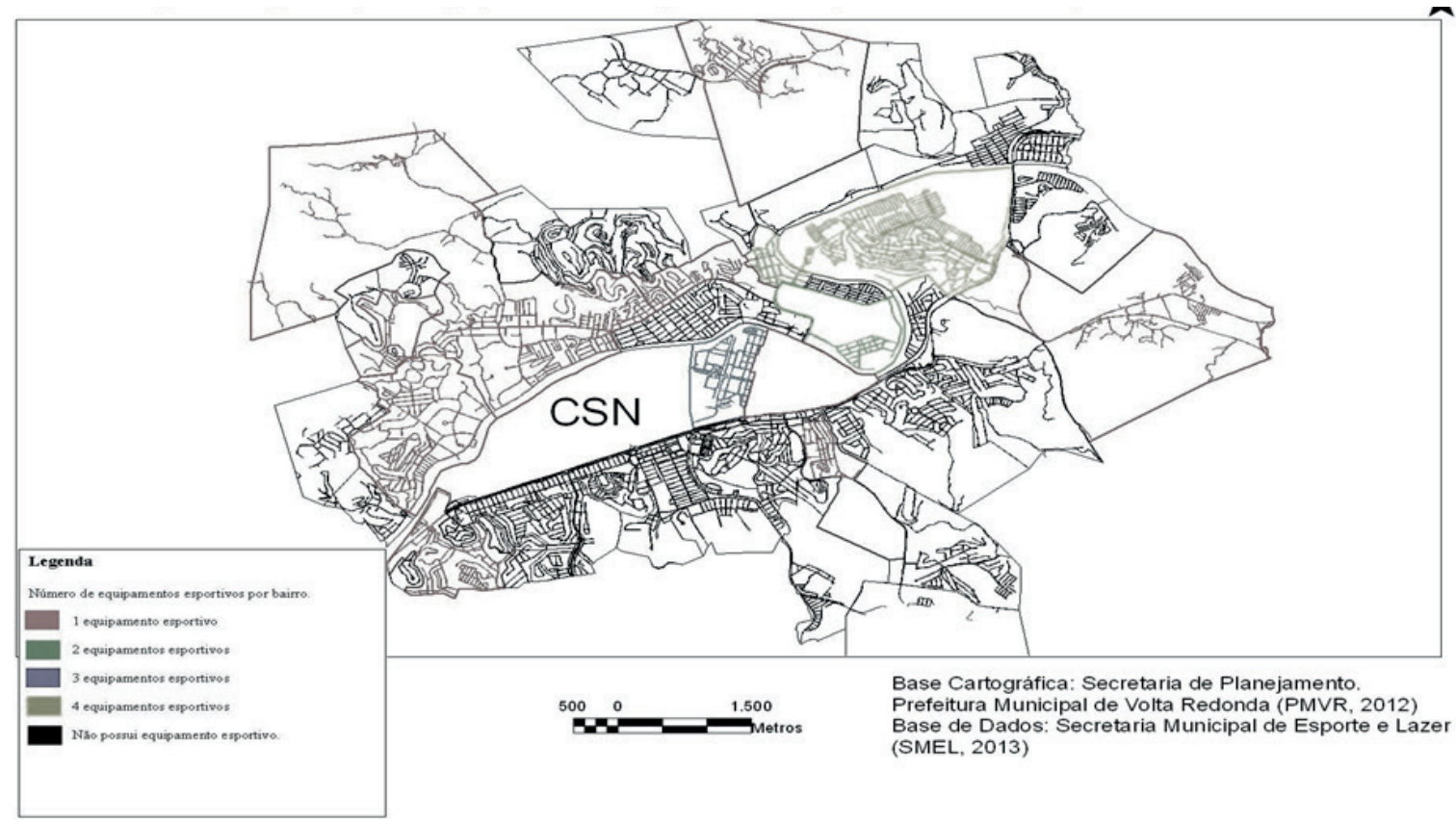

Fonte: Elaborado pelo Autor, 2013.

Tabela 5. Índice de Desenvolvimento Esportivo (IDE) do estado do Rio de Janeiro

\begin{tabular}{|l|l|l|l|l|l|}
\hline Class. & IDE & Município & Class. & IDE & Município \\
\hline 1 & 3,58 & Volta Redonda & 11 & 3,00 & Porto Real \\
\hline 2 & 3,16 & Campos dos Goytacazes & 12 & 2,97 & Niterói \\
\hline 3 & 3,10 & Resende & 13 & 2,97 & Paty dos Alferes \\
\hline 4 & 3,10 & Santa Maria Madalena & 14 & 2,97 & Angra dos Reis \\
\hline 5 & 3,10 & Barra Mansa & 15 & 2,97 & Mangaratiba \\
\hline 6 & 3,03 & Cardoso Moreira & 16 & 2,90 & Conceição de Macabu \\
\hline 7 & 3,03 & Macaé & 17 & 2,90 & São João da Barra \\
\hline 8 & 3,03 & Macuco & 18 & 2,90 & Vassouras \\
\hline 9 & 3,03 & Quissamã & 19 & 2,87 & Rio das Ostras \\
\hline 10 & 3,03 & Rio das Flores & 20 & 2,84 & Barra do Piraí \\
\hline
\end{tabular}

Fonte: Índice de Desenvolvimento do Esporte. Cartilha Elaborada pela Superintendência de Desportos do Estado do Rio de Janeiro (Suderj), 2011. Disponível em: http://www.suderj.rj.gov.br. ${ }^{9}$

9 Índice de Desenvolvimento do Esporte (IDE). Elaborado pela Superintendência de Desportos do estado do Rio de Janeiro (SUDERJ), 2011. Disponível em: http://www.suderj.rj.gov.br. 
Volta Redonda anunciou novos investimentos esportivos para os próximos anos. Está em construção a Vila Olímpica, que contará com um espaço de $35 \mathrm{mil} \mathrm{m}^{2}$ para a prática de atletismo em alto nível, com pistas destinadas a provas de corrida, salto e arremesso, certificadas internacionalmente pela Associação Internacional de Federaçôes de Atletismo (IAAF), em convênio com o governo estadual, no valor de $\mathrm{R} \$ 12$ milhōes. Além disso, está prevista a construção de um ginásio para a prática de ginástica artística no valor de $\mathrm{R} \$ 8$ milhōes. A seguir, apresentamos dois equipamentos esportivos de propriedade da prefeitura e seus usos.

\section{0 estádio Sylvio Raulino de Oliveira}

No final dos anos 1940, o general Sylvio Raulino de Oliveira, então presidente da CSN, financiou, com recursos da empresa, a construção de um estádio de futebol, que veio a ser inaugurado em 1951. Mais tarde, o estádio ganhou o nome de seu mentor. Com o crescimento e a popularização do futebol, o objetivo da empresa era criar um espaço para que os trabalhadores e suas famílias participassem de jogos e também assistissem às partidas. Em 1959, Raulino transferiu a administração do estádio para o Guarani Futebol Clube, por meio de comodato com duração de quatro anos. Na década de 1960, o então presidente da CSN, Osvaldo Pinto da Veiga, determinou que se fizesse a iluminação do estádio.

Na década de 1970, houve a ideia de se criar um time próprio da cidade, e o prefeito à época, Nelson Gonçalves, reformou o estádio, ampliando sua capacidade, pois o novo time jogaria contra outras equipes do estado. Porém, o prefeito queria uma garantia de que efetivamente esse time seria criado. Houve, então, uma reunião entre a Prefeitura, a CSN e a Confederação Brasileira de Desportos (atual Confederação Brasileira de Futebol - CBF) para a reforma do estádio e a criação do time, processo que durou sete meses. Assim, em 1976, após a fusão dos estados do Rio de Janeiro e da Guanabara, nasceu o Volta Redonda Futebol Clube, para a disputa do novo campeonato estadual de futebol.

Em 1976, o prefeito desapropriou o estádio, pois o terreno pertencia à CSN.${ }^{10} \mathrm{O}$ estádio tinha capacidade para 25 mil pessoas, contava com arquibancadas de madeira com estrutura metálica e apresentava características simples. De acordo com a Prefeitura, ${ }^{11}$ em 2001 o prefeito Antônio Francisco Neto acatou a proposta do jornalista e assessor Oscar Cardoso e iniciou a reforma do estádio. Com recursos próprios do município, na ordem de $\mathrm{R} \$ 16$ milhōes, após três anos de obras, surgiu um novo estádio de arquitetura moderna (Figura 4). Com capacidade reduzida para vinte mil pessoas, insere-se nas normas do Estatuto do Torcedor - de acordo com a prefeitura, o novo espaço oferece mais conforto, beleza e segurança em seu interior.

O estádio é considerado o primeiro do Brasil a abrigar um complexo de esportes, lazer, saúde e educação, com acesso gratuito à população. Entretanto, sem contar com um time pro-

\footnotetext{
${ }^{10}$ Informações fornecidas pela Prefeitura Municipal de Volta Redonda (PMVR). Para mais informações, acessar: http://www.portalvr.com/estadiodacidadania/index.php/o-estadio/comeco.

${ }^{11}$ Idem.
} 
fissional que tenha grande torcida e que dispute os principais campeonatos de futebol do Brasil, fica subutilizado no que concerne à realização de eventos esportivos, fato que gera críticas por parte daqueles que o consideram um grande investimento esportivo que não traz retorno para o município. A prefeitura, contudo, alega que o movimento proporcionado pelas partidas de futebol no município, principalmente das grandes equipes da capital, traz diversos benefícios para a economia da cidade. Em dias de jogos, os serviços e comércios recebem um grande fluxo de turistas que chegam para assistir às partidas. Além disso, a imagem da cidade é divulgada em todo o território nacional e também no exterior, com a transmissão das partidas pela televisão. Em 2013, o investimento foi de cerca de R\$ 150 mil em melhorias e manutenção do estádio, como recapeamento, pinturas da pista de acesso ao estádio e nas dependências, além de reforma nos vestiários. Além disso, a operacionalização e a manutenção do estádio custam, de acordo com a prefeitura, cerca de $\mathrm{R} \$ 250$ mil. $^{12}$

Figura 4. Foto da entrada principal do estádio municipal Sylvio Raulino de Oliveira

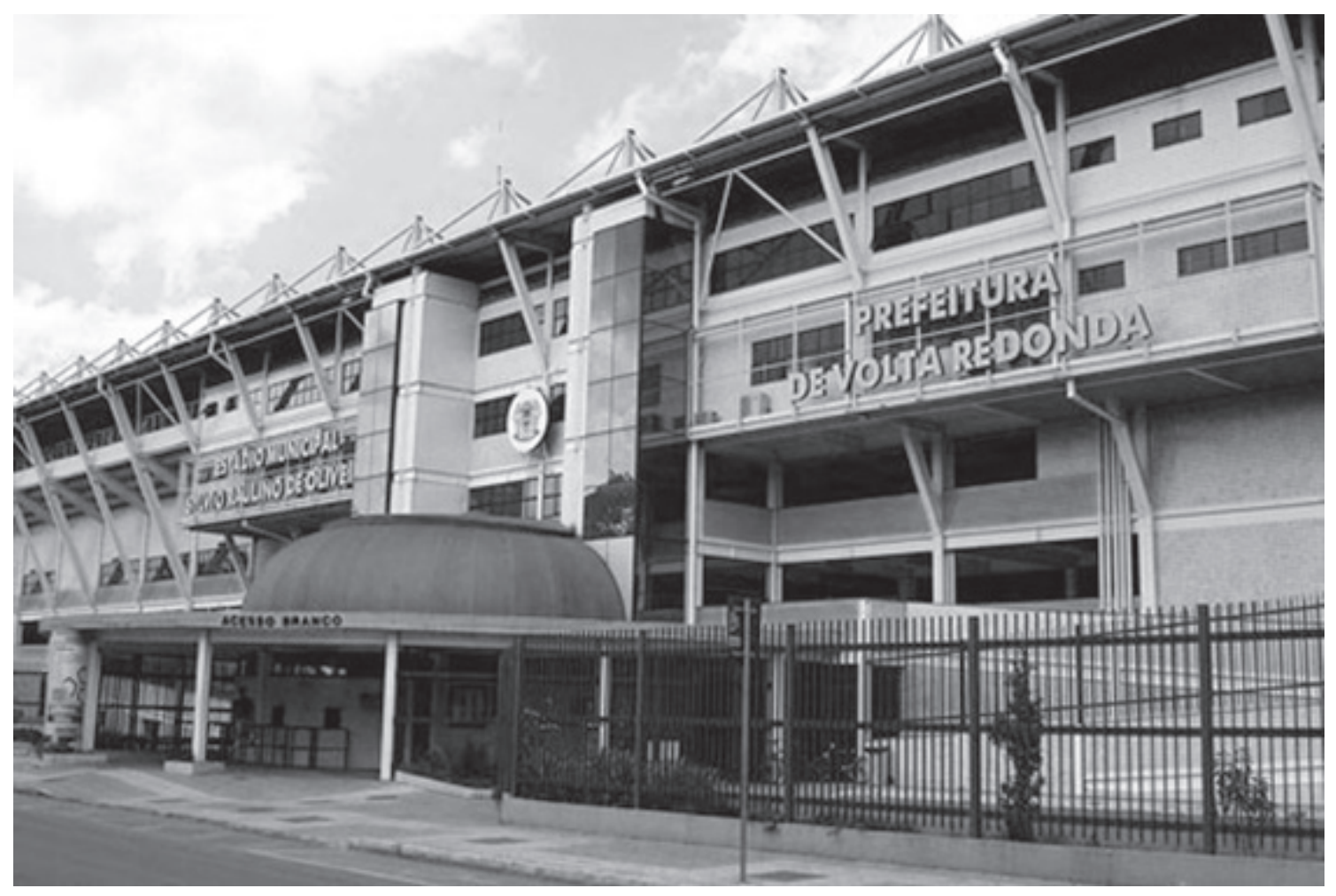

Fonte: Prefeitura Municipal de Volta Redonda. http://www.portalvr.com/estadiodacidadania.

\footnotetext{
${ }^{12}$ Reportagem do jornal Diário do Vale: "Jogos em Volta Redonda trazem visibilidade”, 2013. Disponível em: http://diariodovale.uol.com.br/noticias/1,72947,Jogos-em-VR-trazem-visibilidade.html\#ixzz2Ylg7XnQF.
} 


\section{A espetacularização do lazer em Volta Redonda: os investimentos esportivos}

Na opinião de Carlos Roberto Parente, o Betinho, administrador do Estádio da Cidadania, com a organização desses jogos de futebol, Volta Redonda mostra que tem condições estruturais de receber grandes eventos esportivos, devido ao "movimento financeiro que a cidade recebe, com a vinda dos torcedores. Já no aspecto de divulgação, os jogos ajudam na publicidade de uma imagem positiva da cidade e do Estádio da Cidadania". ${ }^{13}$ Outro argumento comum é a escolha do estádio como subsede da Copa do Mundo de 2014. Em 2012, o local foi alvo de inspeção por parte da Federação Internacional de Futebol (Fifa), que vistoriou todas as instalações e selecionou 54 delas que foram aprovadas como Centros de Treinamento de Seleções (CTS), podendo ser utilizadas pelas seleções de futebol classificadas para a Copa do Mundo. Com isso, o Ministério do Esporte, em convênio com a Prefeitura, liberou $\mathrm{R} \$ 800$ mil para a realização de obras de reparos gerais e modernização, além de reformas para melhorar a acessibilidade. Entretanto, durante a realização da Copa do Mundo, nenhuma das 32 seleções escolheu a cidade como local de preparação para a competição, não dando o esperado retorno para os investimentos realizados.

Mesmo assim, quando há jogo, principalmente das grandes equipes da capital do estado, o que se vê são milhares de visitantes, o que deixa o trânsito no entorno do estádio bastante complicado. Muitos ônibus e vans estacionam ao redor de praças e ruas próximas, tumultuando ainda mais o fluxo de veículos. A maioria vem de cidades vizinhas e da capital do estado. Assim, os estabelecimentos comerciais (bares, restaurantes e lojas) ficam cheios, e as pessoas têm de enfrentar filas e muito tempo de espera. Mas, apesar desses problemas, a prefeitura defende que a organização desses jogos e eventos prova que a cidade já está preparada para a realização de grandes eventos

Gostaria de ressaltar que a divulgação da cidade até para o exterior foi um dos principais benefícios. Volta Redonda sempre foi considerada a Cidade do Aço e nos orgulhamos disso. Mas com essa publicidade podemos nos mostrar como a cidade do esporte, da saúde e da cultura também. ${ }^{14}$

$\mathrm{O}$ administrador do estádio explica que, a cada jogo, o custo operacional gira em torno de $\mathrm{R} \$$ 15 mil - com cerca de duzentos funcionários terceirizados, entre limpeza, bilheteiro, roleteiro e apoio. Conforme veiculado no jornal Diário do Vale, ${ }^{15}$ para Jessé Holanda, secretário de Turismo, a vinda de jogos para a regiāo trouxe visibilidade para Volta Redonda, além de movimentar hotéis, bares e restaurantes, e isso não só pela vinda de torcedores, mas também pelas delegações e jornalistas que vêm para cobrir as partidas. Para o presidente do Sindicato do Comércio Varejista de Volta Redonda, Antônio Borges, eventos que "promovem o movimento de pessoas e o aumento da circulação de dinheiro beneficiam o comércio da cidade" ${ }^{16}$

Por ser um estádio que concentra atividades não somente ligadas ao esporte, mas também a saúde, lazer e educação para a população do município, passou a ser chamado pela prefeitura de "Es-

\footnotetext{
${ }^{13}$ Idem.

${ }^{14}$ Idem.

${ }^{15}$ Idem.

${ }^{16}$ Idem.
} 
tádio da Cidadania". Assim, a prefeitura procura apagar a memória da cidade como ligada à "Cidade do Aço" e reconstruir uma nova imagem, dotando o município de novos significados, como, por exemplo, a cidadania. Um dos principais instrumentos utilizados pela prefeitura nesse sentido é o discurso, cuja dimensão é muito maior que as ações realizadas em termos de políticas públicas. Entretanto, a população, que deveria protagonizar o papel de agente da história do município, muitas vezes se acomoda como receptora das benesses concedidas pela prefeitura.

A reforma do Estádio da Cidadania é um marco na construção da cidade após os anos de crise vividos com a privatização da CSN. A Prefeitura enaltece uma cidadania que é passiva, em que o cidadão se contenta em ter seus direitos civis e políticos tutelados pela intervenção do poder público municipal, através de um forte processo de regulação. Os eventos e espetáculos teoricamente acessíveis a todos constroem, junto à população, essa ideia de cidadania. Além disso, essa imagem se baseia nas ideias de um desenvolvimento sustentado em outras bases que não apenas a indústria, mas também atraindo investimentos nos setores de comércios e de serviços, nos quais aparecem como destaque os eventos esportivos e culturais, visando ao aumento de empregos e da arrecadação tributária (Oliveira e Mascarenhas, 2007).

\subsection{O complexo esportivo da Ilha São João}

O complexo da Ilha São João, cujo nome oficial é Complexo de Atividades Duque de Caxias, foi criado pelo primeiro prefeito nomeado quando da transformação da cidade em área de segurança nacional, durante a ditadura militar - o engenheiro Georges Leonardo, em 1973. Na ocasião, a prefeitura desapropriou as ilhas do complexo com a intenção de tornar a área um local voltado à cultura, ao esporte e ao lazer da população da cidade. No passado, o local pertencera à antiga Fazenda São João Batista. Com a diminuição dos investimentos em lazer por parte da CSN, a Prefeitura considerou que havia necessidade de reformar/revitalizar esse equipamento de lazer com atividades culturais e esportivas para a população.

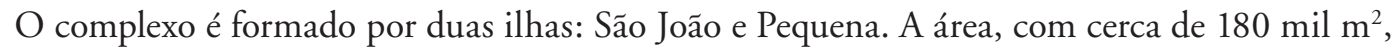
possui ginásio coberto, quadra aberta e quadra de areia, pista de caminhada, pavilhão de atividades múltiplas, centro de exposiçóes, miniestádio, escola de hipismo, minicidade do trânsito, posto médico, sede da Secretaria Municipal de Lazer, da Guarda Municipal e da Defesa Civil, além de um espaço do Detran.

Os principais eventos realizados anualmente estão ligados a esportes, feiras de negócios e exposições culturais e artísticas, como Expo-VR, Expo Agro, Feira Estadual da Indústria Metalmecânica, Médio Paraíba Negócios, Feira da Primavera, Festa do Peão Boiadeiro, carnaval, VR Folia, Encontro de Motoqueiros, Encontro de Carros Antigos, Encontro Nacional de Evangélicos, Olimpíadas das Pessoas Portadoras de Necessidades Especiais, Jogos Estudantis e Copa Regional Diarinho do Vale.

A Ilha Pequena conta com uma área de $25 \mathrm{mil} \mathrm{m}^{2}$, onde se situam as instalaçôes da Escola Municipal de Remo e do Parque Aquático, ambos administrados pela prefeitura, por meio da Secretaria Municipal de Esporte e Lazer. A Escola Municipal de Remo foi inaugurada em 2011, com as raias de treinamento e competição localizadas no rio Paraíba do Sul, junto à Defesa Civil. A escola promove atividades de iniciação à modalidade esportiva de remo e atividades educacionais sobre 


\section{A espetacularização do lazer em Volta Redonda: os investimentos esportivos}

meio ambiente e recursos hídricos, tendo, como público-alvo, jovens em idade escolar e matriculados regularmente na rede pública de ensino. O parque aquático foi construído em 1981, com o objetivo de incluir as faixas sociais carentes no lazer e desenvolvimento do esporte aquático no município. Cinco anos depois, em 1986, foi desativado e, em 1997, foi reformado e reativado, embora só tenha passado a funcionar plenamente em 2001. A Figura 5 mostra a festa de comemoração dos dez anos de funcionamento do parque.

O local conta com uma estrutura física de $11.300 \mathrm{~m}^{2}$, distribuídos entre três piscinas (uma de tamanho olímpico destinada a esportes aquáticos, uma infantil e outra para recreação), cantinas, vestiários, secretaria, sala de professores e uma arquibancada para quinhentos espectadores. De acordo com a prefeitura, são oferecidos gratuitamente à população de Volta Redonda cursos de natação, hidroginástica e polo aquático. Uma das exigências para ter acesso ao parque aquático e aos cursos é comprovar residência na cidade. Assim, são atendidas diariamente cerca de três mil pessoas em atividades recreativas. O local tem um total 5.480 alunos matriculados em seus cursos e conta com 11 professores e seis estagiários. No total, o espaço tem sessenta mil associados.

Os investimentos da prefeitura direcionados à manutenção e à operacionalização do parque aquático para 2013 eram estimados em R \$ 1,5 milhão. Com a escolha do local para a aclimatação das delegações para as Olimpíadas, a Prefeitura tencionava investir anualmente R \$ 1,5 milhão, por meio de convênios com o Ministério de Esportes, para a recuperação e a revitalização do local, a fim de se adequar às exigências do Comitê Olímpico Internacional (COI). Além desses interesses, o parque aquático é apresentado pela prefeitura como um local que preza pela melhor qualidade de vida dos cidadãos de Volta Redonda.

Figura 5. Foto de comemoração de 10 anos de funcionamento do parque aquático

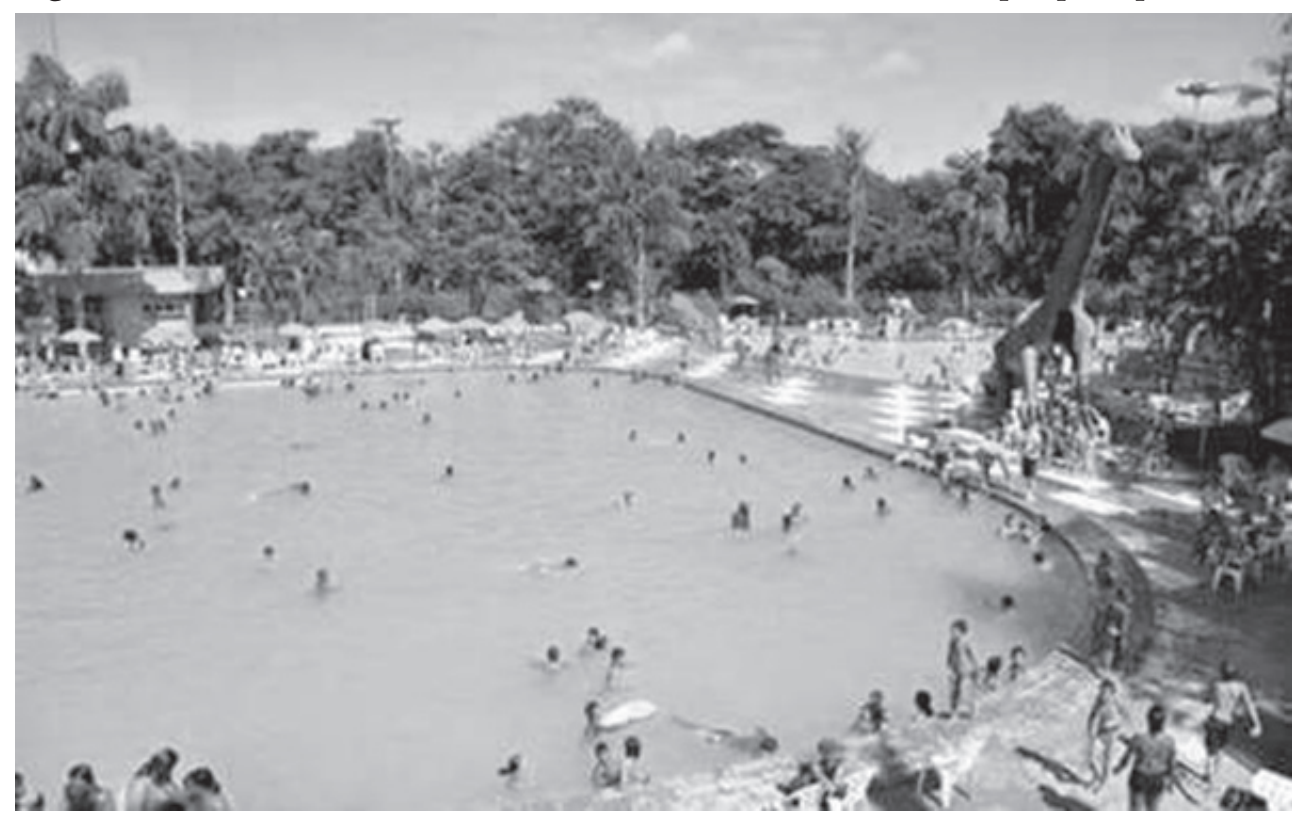

Fonte: Jornal Diário do Vale, 2011. 
O Parque Aquático Municipal proporciona gratuitamente à população de Volta Redonda esporte e lazer, através da prática de atividades aquáticas. Com espaço físico privilegiado por sua estrutura e beleza natural, o Parque Aquático Municipal de Volta Redonda oferece uma excelente opção de lazer, recreação e convívio social, buscando, com isso, melhor qualidade de vida aos cidadãos do município. ${ }^{17}$

O ginásio coberto poliesportivo General Euclydes Figueiredo, inaugurado em 1982, tem capacidade para seis mil pessoas. O local, além de promover a prática de atividades esportivas, por meio de programas/projetos voltados à população, tem como característica principal a realização de eventos esportivos profissionais de alto nível. Na Figura 6, vê-se a infraestrutura do ginásio. O local ainda conta com uma pista de caminhada de $800 \mathrm{~m}$ de extensão e um centro esportivo - o Oscar de Carvalho, inaugurado em 2004 -, que possui uma quadra de futebol society, uma sala de administração, quatro cantinas, quatro vestiários, tribuna de honra e arquibancada para cinco mil pessoas. No local, também existe a escola municipal de hipismo, criada em 2003 para ensinar crianças com até 14 anos, com todas as despesas custeadas pela Prefeitura. A imagem das duas ilhas e de toda a sua infraestrutura pode ser observada na Figura 7.

Figura 6. Fotografia da parte interna do ginásio mostrando a quadra e parte da arquibancada

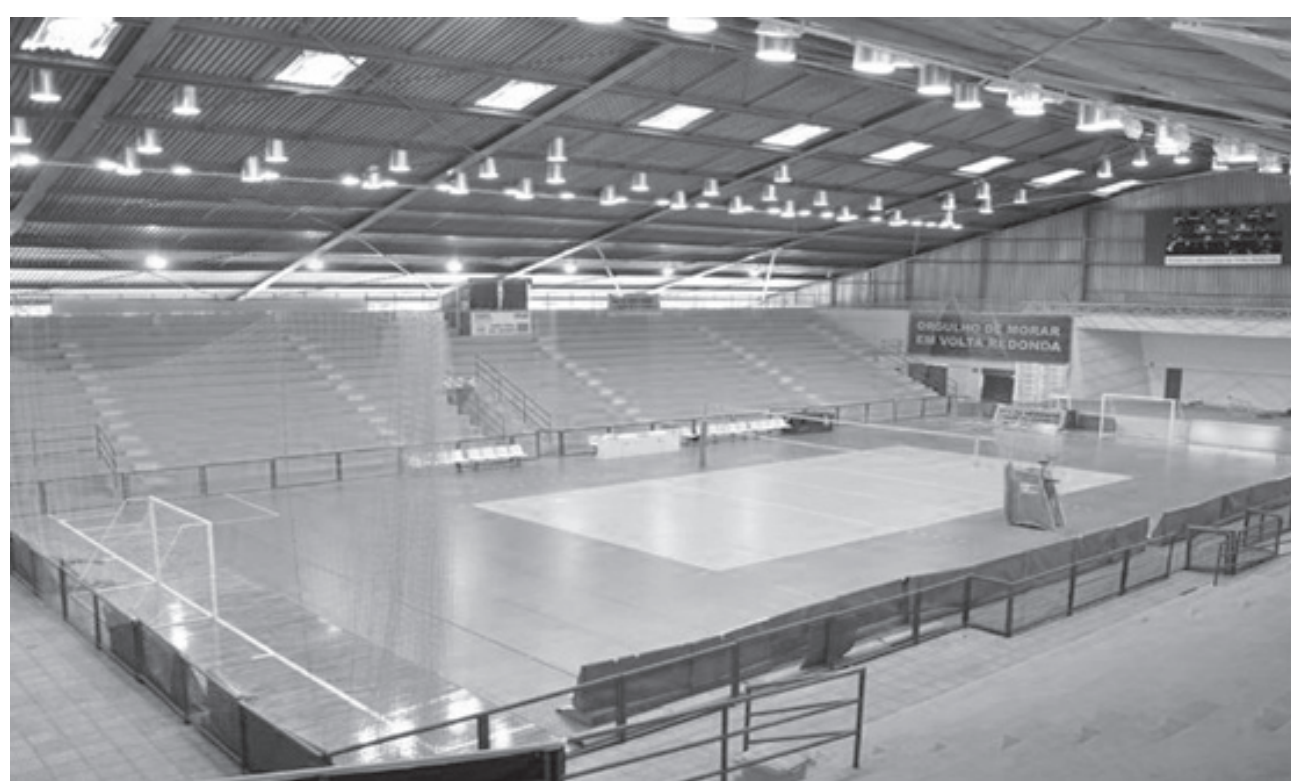

Fonte: Secretaria Municipal de Esporte e Lazer, 2013.

\footnotetext{
${ }^{17}$ Retirado do site: http://www.portalvr.com/smel/parqueaquatico.php
} 


\section{A espetacularização do lazer em Volta Redonda: os investimentos esportivos}

Figura 7. Vista aérea do complexo com a Ilha São João e Ilha Pequena

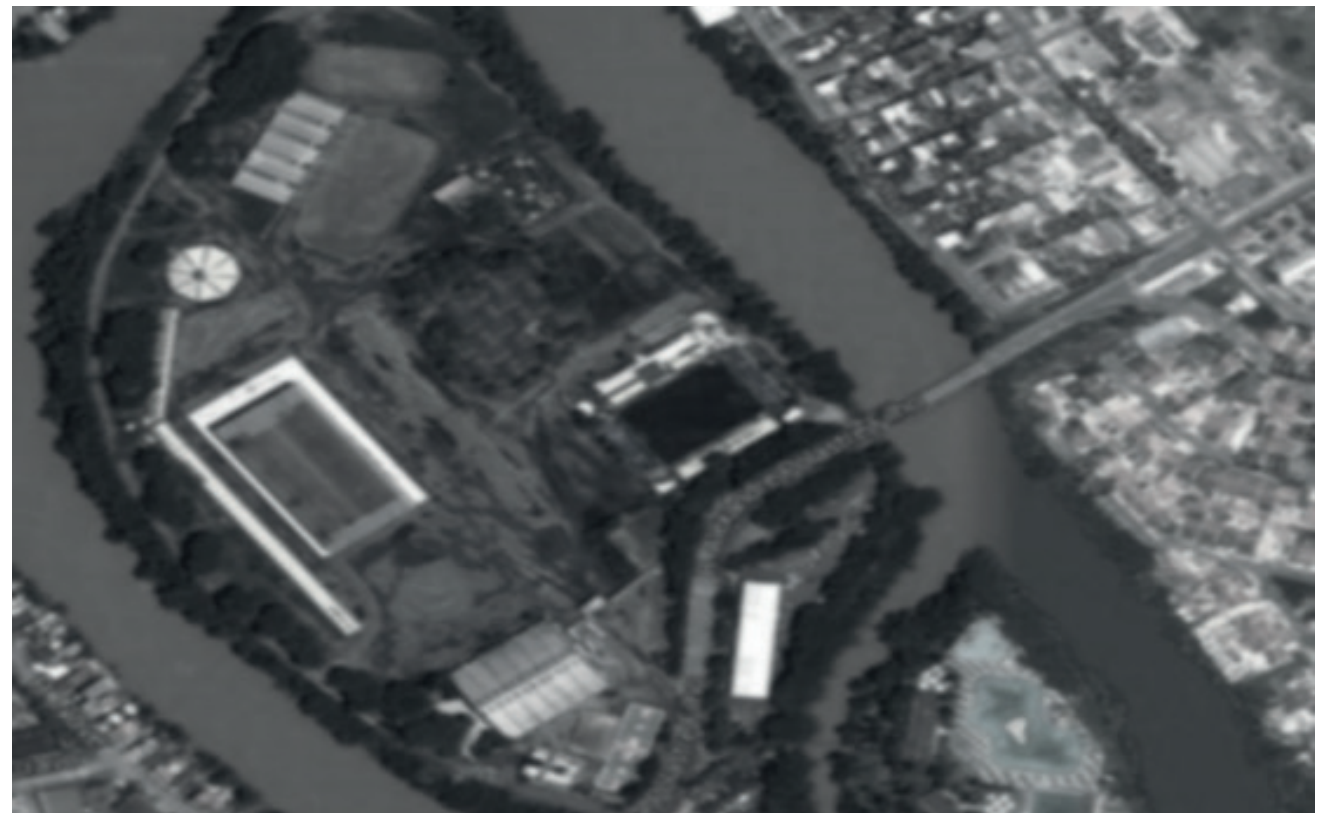

Fonte: Google Earth, 2013.

\section{Considerações finais}

Constatamos que a reestruturação produtiva e territorial por que passa Volta Redonda promoveu alteração nos equipamentos e atividades de lazer, com inúmeras consequências para a dinâmica urbana. $\mathrm{O}$ aumento da atuação do poder público municipal pode ser comprovado pelo elevado número de eventos esportivos e culturais realizados anualmente na cidade.

O lazer insere-se no conjunto de políticas do poder público municipal, com a tentativa de desvincular a imagem da cidade em relação à siderúrgica. Entretanto, os elementos simbólicos ligados à "Cidade do Aço" ainda se mostram muito presentes, como a toponímia das ruas e praças e os equipamentos urbanos da cidade, carregados pelo contexto do aço.

$\mathrm{O}$ conjunto de açōes que visam à transformação da imagem do município é relativamente recente, pois parte das famílias tem suas histórias de vida relacionadas, direta ou indiretamente, à usina ou ao contexto de sua criação, ou seja, à cidade siderúrgica. Por meio de seu discurso, dos investimentos e da recuperação/criação de novos símbolos na cidade (como o Estádio da Cidadania e o Complexo da Ilha São João), o Poder Público municipal procura alterar o paradigma do município para uma cidade de qualidade de vida baseada na cidadania. Nesse sentido, emprega recursos materiais (como estruturas e equipamentos) e imateriais (como serviços, sobretudo os discursos utilizados) para realçar suas novas virtudes, por meio de símbolos elaborados para produzir uma nova imagem para o lugar e utilizá-la para atrair novos investimentos. Essa questão é discutida por Milton Santos (2004), 
segundo o qual essa busca dos lugares para se diferenciar com o objetivo de atrair novos investimentos é chamada "guerra dos lugares".

Sem dúvida, esses investimentos em lazer trazem benefícios para a população, mas precisam ser questionados, pois o lazer da cidade se inscreve no modelo capitalista, com a produção da imagem de cidade com boa qualidade de vida e cidadania, um discurso que, paulatinamente, vai ganhando legitimidade junto à população, assim como a crença de que a prefeitura é responsável por todos os problemas existentes no município. A população, portanto, vive naquilo que Baudrillad (1981) chama de "simulacro", em que tudo parece estar em perfeita harmonia com o retorno do orgulho de uma cidade como exemplo para o país: se antes era por ser uma cidade moderna e industrial, por causa da CSN, atualmente é por ser uma cidade que promove cidadania para toda a sua população.

Assim, a reforma/construção de equipamentos urbanos modernos, inclusive daqueles destinados ao lazer, é apresentada por inúmeras propagandas, que os tornam mais atraentes ao agora cidadão do que o próprio objeto em sua realidade. Por meio de uma série de atividades e eventos de lazer, com destaque para os esportivos, o município passa a se configurar como exemplo de sociedade espetacularizada, o que, para Débord (1998), leva os indivíduos a contemplarem e a consumirem passivamente essas imagens, que, nesse caso, estão fortemente vinculadas à prefeitura, perdendo-se o sentido da vivência no espaço urbano.

Com isso, é possível afirmar que as mudanças do lazer na cidade impactaram a dinâmica urbana do município, com a alteração no fomento da prática de lazer. Enquanto a empresa visava ao lazer em um contexto fordista, atualmente, com o fomento pela prefeitura, esse lazer apresenta aspectos diferenciados, associados ao contexto atual da cidade pós-fordista. Entretanto, as mudanças mais acentuadas não ocorreram nas práticas das atividades de lazer, pois, se antes os principais eventos e atividades eram os socioculturais e esportivos, atualmente ainda apresentam grande relevância. A mudança mais significativa foi na função do lazer, pois, se antes a principal característica era o aspecto funcionalista e utilitarista por parte da empresa para seus funcionários, hoje se apresenta como um simulacro, espetacularizado por parte da Prefeitura para os cidadãos.

\section{Referências}

BAUDRILLARD, Jean. Simulacro e simulaçōes. Lisboa: Relógio D’Água, 1981. 202 p. (Coleção Antropos). CALIFE, Magali Nogueira da Silva. A relação entre capital-trabalho na gênese da CSN (dissertação). Universidade Severino Sombra, 2000.

COSTA, Alkindar. Volta Redonda, ontem e hoje. 3 ed. Volta Redonda-RJ: Masiero's, 1992.

DEBORD, Guy. A sociedade do espetáculo. 2 ed. Rio de Janeiro: Contraponto, 1997. 240p.

DIÁRIO DO VALE. "Comemoração aos 10 anos de Funcionamento do Parque Aquático Municipal de Volta Redonda”, jornal Diário Regional, Volta Redonda, 2011. Disponível em: http://diariodovale.uol.com. br/noticias/0,37608,Parque\%20Aquatico\%20da\%20Ilha\%20Sao\%20Joao\%20completa\%2010\%20 anos.html\#axzz2aOOXTJnY Acesso em: 10 maio 2013. 
—. "Aprovação da Fifa rende R \$ 800 mil a Volta Redonda”, jornal Diário Regional, Volta Redonda, 2013. Disponível em: http://diariodovale.uol.com.br/noticias/6,71529,Aprovacao-da-Fifa-rende-R \$-800-mil-a-Volta-Redonda.html\#ixzz2Ylj1lwxu. Acesso em: 10 maio 2013.

. "Jogos em Volta Redonda trazem visibilidade”, Diário Regional, Volta Redonda, 2013. Disponível em: http://diariodovale.uol.com.br/noticias/1,72947,Jogos-em-VR-trazemvisibilidade. html\#ixzz2Ylg7XnQF. Acesso em: 10 maio 2013.

FONTES, Ângela Maria Mesquita e LAMARÃO, Sérgio Tadeu Niemeyer. "Volta Redonda: história de uma cidade ou de uma usina”. Revista Rio de Janeiro, Niterói, n. 18-9, jan.-dez. 2006, pp. 241-53.

GOVERNO FEDERAL. Portal da Transparência. [Consulta ao Setor de Convênios]. Disponível em: http:// www.portaltransparencia.gov.br/convenios. Acesso em: 10 dez. 2011.

JORNAL AQUI. "Não é mais o mesmo". Diário Local, Volta Redonda-RJ. Disponível em: http://www. jornalaqui.com.br/arquivo/2011/744/paginas/csn3.htm. Acesso em: 15 jan. 2013.

LOPES, Alberto da Costa. A aventura da cidade industrial de Tony Garnier em Volta Redonda (dissertação). UFRJ, 1993.

MOREIRA, Regina da Luz. CSN: um sonho feito de aço e ousadia. 1 ed. Rio de Janeiro: Fundação CSN/ CPDOC/Fundação Getulio Vargas/Iarte, 2000. 191p.

OLIVEIRA, Leandro Dias de e MASCARENHAS, Gilmar. "A criação do Estádio da Cidadania em Volta Redonda-RJ: uma reflexão sobre simbolismo e ideologia na paisagem urbana”. Colóquio Nacional do Núcleo de Estudos em espaço e representações (NEER). Anais... Salvador, 2007.

PALMEIRA, André Franklin. A nova face da Cidade do Aço: crise do capital, trabalho e hegemonia em Volta Redonda (1992-2008) (dissertação). UFF, 2012.

PIQUET, Rosélia. Cidade-empresa: presença na paisagem urbana brasileira. Rio de Janeiro: Jorge Zahar, 1998. 166p.

RIO DE JANEIRO. Secretaria de Esporte e Lazer. Índice de Desenvolvimento do Esporte (IDE). Rio de Janeiro: Suderj, 2011. Disponível em: http://www.suderj.rj.gov.br. Acesso em: 08 dez. 2011.

SANTOS, Milton. A natureza do espaço: técnica e tempo. Razão e emoção. 4 ed. São Paulo: EDUSP, 2002. $384 \mathrm{p}$.

SOUTO, Baiena Feijolo. "Volta Redonda hoje: novos movimentos migratórios, primeiras aproximaçōes". Encontro Nacional sobre Migração, 5. Anais... Campinas, 2007. 22p.

TESOURO NACIONAL. Dados contábeis dos municípios brasileiros, 2010. Finanças do Brasil (Finbra). Disponível em: http://www.stn.fazenda.gov.br/estados_municipios/index.asp. Acesso em: 01 dez. 2011.

—. Sistema Integrado de Administração Financeira (SIAFI) [Consulta execução orçamentária, financeira e patrimonial do Governo Federal]. Disponível em: http://www.tesouro.fazenda.gov.br/siafi. Acesso em: 05 dez. 2011.

TUBINO, Manoel. O que é esporte? 3 ed. São Paulo: Brasiliense, 2006. 55p. (Coleção Primeiros Passos)

VOLTA REDONDA. Prefeitura Municipal. Lei Orgânica Municipal. Volta Redonda, 1992. 103p.

—. Cidade do esporte. Secretaria Municipal de Esporte e Lazer. Volta Redonda, v. 1, 2013. 10p.

—. Estádio da Cidadania. Secretaria Municipal de Esporte e Lazer. Disponível em: http://www.portalvr. com/estadiodacidadania. Acesso em: 10 abr. 2013.

—. Parque Aquático. Secretaria Municipal de Esporte e Lazer. Volta Redonda, 2013. Disponível em: http:// www.portalvr.com/smel/parqueaquatico.php. Acesso em: 10 abr. 2013. 